\title{
The potential for luxury resort developments in Croatia
}

Received: 26 October 2007

\section{Arlett Oehmichen}

is an Associate with HVS International's London office, specialists in hotel valuation and consultancy. She joined HVS in mid-2006 after six months experience in the hotel investment industry as well as operational hotel experience during university placements with Hilton and NH Hoteles. Arlett has studied Business Administration at the Dresden University of Technology, Germany and Universidad de Cordoba, Spain. Since joining HVS, she has conducted numerous valuations and feasibility studies in Europe and Northern Africa. Arlett has worked on assignments for hotels as well as mixed-use developments comprising residential components, rental pools, golf courses and marinas.

\section{Dominique Bourdais}

is a Director in the London office of HVS International. His background is that of a trained hotelier. Before entering the consultancy world, he worked for Forte Hotels in the UK and Sheraton in West Africa. He has more than 20 years specialist hotel consultancy experience. He has been with HVS International for nine years. During his years as a management consultant he has gained substantial international experience, having completed a wide range of hotelrelated assignments, while diversifying into other fields such as extended stay hotels, serviced apartments, other areas of real estate, golf and leisure, and mergers and acquisitions. His work within HVS International generally focuses on the provision of specialist hotel valuation, property and consultancy services throughout Europe, the Middle East, Africa and Asia. Dominique has extensive experience of Central and Eastern Europe and he is responsible for the development of HVS International's business in that region.

\begin{abstract}
An unspoilt nature, numerous cultural sites, more than 1,100 islands, a mild Mediterranean climate, a strong economic recovery in recent years, the expected accession to the EU and a lack of luxury accommodation make Croatia the current hotspot for resort development in the Mediterranean Basin. This paper will highlight the potential for resort developments in Croatia but also the possible downsides.
\end{abstract}

\section{Keywords:}

Croatia, luxury resorts, golf, rental, marinas

Journal of Retail and Leisure Property (2007) 6, 311-325. doi:10.1057/palgrave.rlp.5100077

Arlett Oehmichen HVS International 7-10 Chandos Street Cavendish Square London $\mathrm{W}_{1} \mathrm{G} 9 \mathrm{DQ}$, UK Tel: +44 (20) 78787700 Fax: +44 (20) 78787799 E-mail: aoehmichen@hvs.com Web: www.hvs.com

\section{INTRODUCTION}

An unspoilt nature, numerous cultural sites, more than 1,100 islands, a mild Mediterranean climate, a strong economic recovery in recent years, the expected accession to the EU and a lack of luxury accommodation make Croatia the current hotspot for resort development in the Mediterranean Basin. This paper will highlight the potential for resort developments but also the possible downsides. 


\section{COUNTRY SNAPSHOT CROATIA}

The Republic of Croatia is a central European and a Mediterranean country (Figure 1). It borders Slovenia to the west, Hungary to the north, Serbia to the east and Bosnia-Herzegovina to the south. Croatia has a long coastline on the Adriatic Sea, and its borders total 2,028 km.

Since the end of the war in 1995, Croatia's economy and tourism have been constantly growing. In 2006, Croatia experienced GDP growth of 4.8 per cent on the previous year. National GDP growth is forecast to grow by 4.7 per cent in 2007 and 4.4 per cent in 2008. Consumer price inflation was 3.2 per cent in 2006 and it is expected to decline to 2.3 per cent in 2007 and then rise again to 3.0 per cent in 2008. In February 2005, the Stabilisation and Association Agreement with the EU officially came into force and Croatia is advancing towards full EU membership, which is expected to be in 2010 .

Croatia has seen strong growth in foreign direct investment (FDI) over the last five years. According to estimates by the Croatian Bureau of

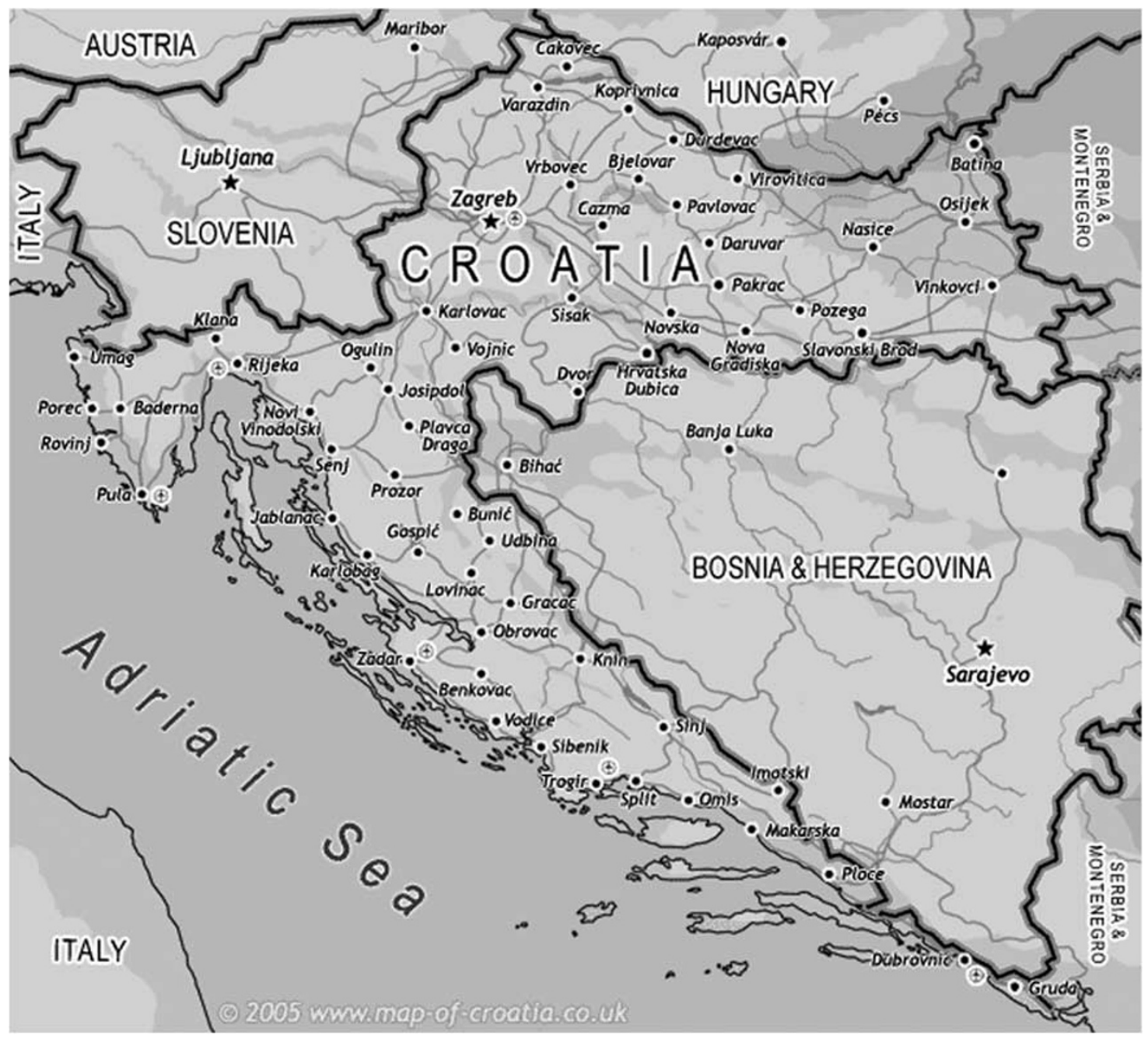

Figure I: The location of Croatia 
Statistics, between 2002 and 2006 FDI grew at a compound annual rate of 17.5 per cent. In 2006 FDI increased almost twofold on 2005 , from $€ 1.8$ to $€ 2.7 \mathrm{bn}$.

\section{Tourist visitation to Croatia}

Tourism in Croatia vanished during the Balkan war (1991-1995) but tourist visitation increased quickly after 1995 . The main reasons for visiting Croatia are as follows:

- Croatia boasts a beautiful landscape, a warm climate, many culinary traditions, a long coastline on the Mediterranean and numerous islands. UNESCO world heritage protected sites include the city of Dubrovnik, the Diocletian's Palace in Split, Plitvice Lakes National Park, the old city of Trogir, the Euphrasius Basilica in Porec and St Jacob's Cathedral in Sibenik.

- The natural attractiveness of Croatia, its unspoiled environment and the offer of a variety of sports and recreational activities, along with the low cost of construction, manpower and final prices compared to other European and Mediterranean countries, has made Croatia a desirable destination for second-home buyers over the last few years.

Over the last 11 years visitation to Croatia has increased by approximately 10 per cent per year (Figure 2 ). The growth in international visitation was particularly strong after the end of the war in 1995 with another drop in tourist visitation in 1999. Over the last five years international visitation has stabilised at about 2.5 million tourists per year. While this figure is close to pre-war levels, it is constrained by the lack of hotel supply and relatively poor accessibility by air compared to other Mediterranean destinations.

Further growth in international visitation is expected with the increase in low-cost carrier routes from Western European destination as well as Croatia's accession to the EU.

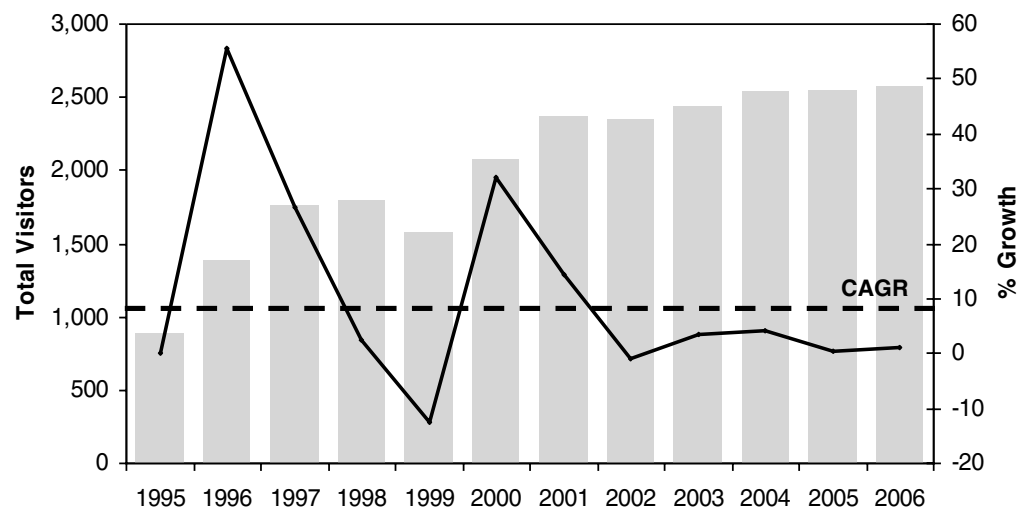

Figure 2: International visitation to Croatia 1995-2006 (000s)

Source: Croatian tourism board. 


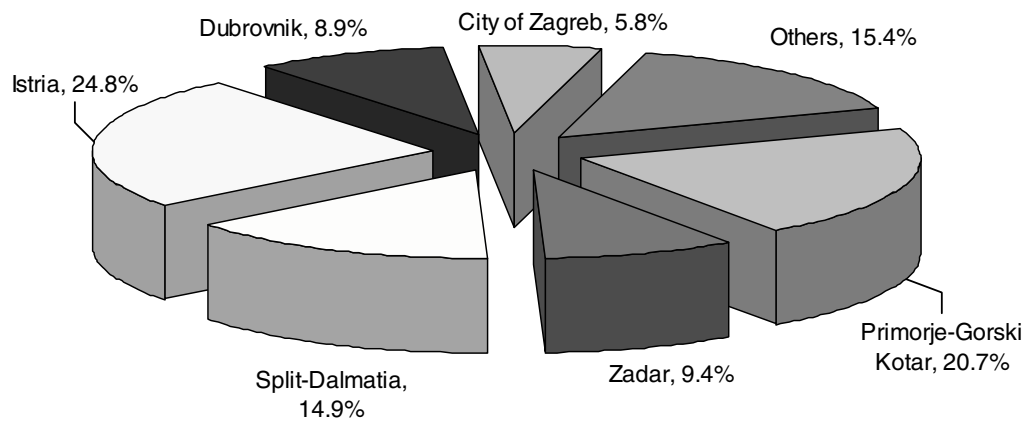

Figure 3: International visitation by region in 2006

Source: Central Bureau for Statistics, Croatia.

As shown in Figure 3 the majority of all international tourists to Croatia stay in Istria (24.8 per cent), followed by Primorje-Gorski Kotar (20.7 per cent) and Split-Dalmatia (14.9 per cent).

Over the last five years passenger numbers at Croatia's main airports have been rising as the country has been rediscovered by many tourists (Figure 4). Apart from Zagreb airport, which is mainly used by business travellers, the three other main Croatian airports have shown double digit compound annual growth rates. This growth has been driven mainly by low-cost carriers such as easyJet or Ryanair introducing new routes from major feeder markets to Croatia.

Zagreb airport, as the main year round port of entry by air, welcomes the most passengers. This is due to the strong corporate market and economic growth in the capital as well as the fact that most international airlines only offer flights via Zagreb to other Croatian cities.

Dubrovnik and Split airports follow Zagreb with approximately 1 million passengers each. Dubrovnik has established itself a hotspot and managed to increase its awareness as a destination overseas and among Western European countries more than any other part of Croatia. Split benefits from a healthy mix of leisure and corporate demand.

Passengers at Pula airport show the lowest passenger numbers compared to the other three airports although the Istrian region as a whole welcomes most tourists (see Table 2). This indicates that most travellers to Istria do not arrive by air but by car from neighbouring countries such as Germany, Italy and Slovenia.

\section{Seasonality}

Despite the strong increase in the number of visitors to Croatia the market remains very seasonal; however, seasonality differs slightly from north to south. Owing to the higher average temperatures in southern Croatia, the main months for visitation are May to October, with July and August being the peak months (Figure 5).

Strengthening Croatia's conference and incentive business and emphasising golf and spa facilities and sailing activities offers possibilities to extend the season and create demand year round. 

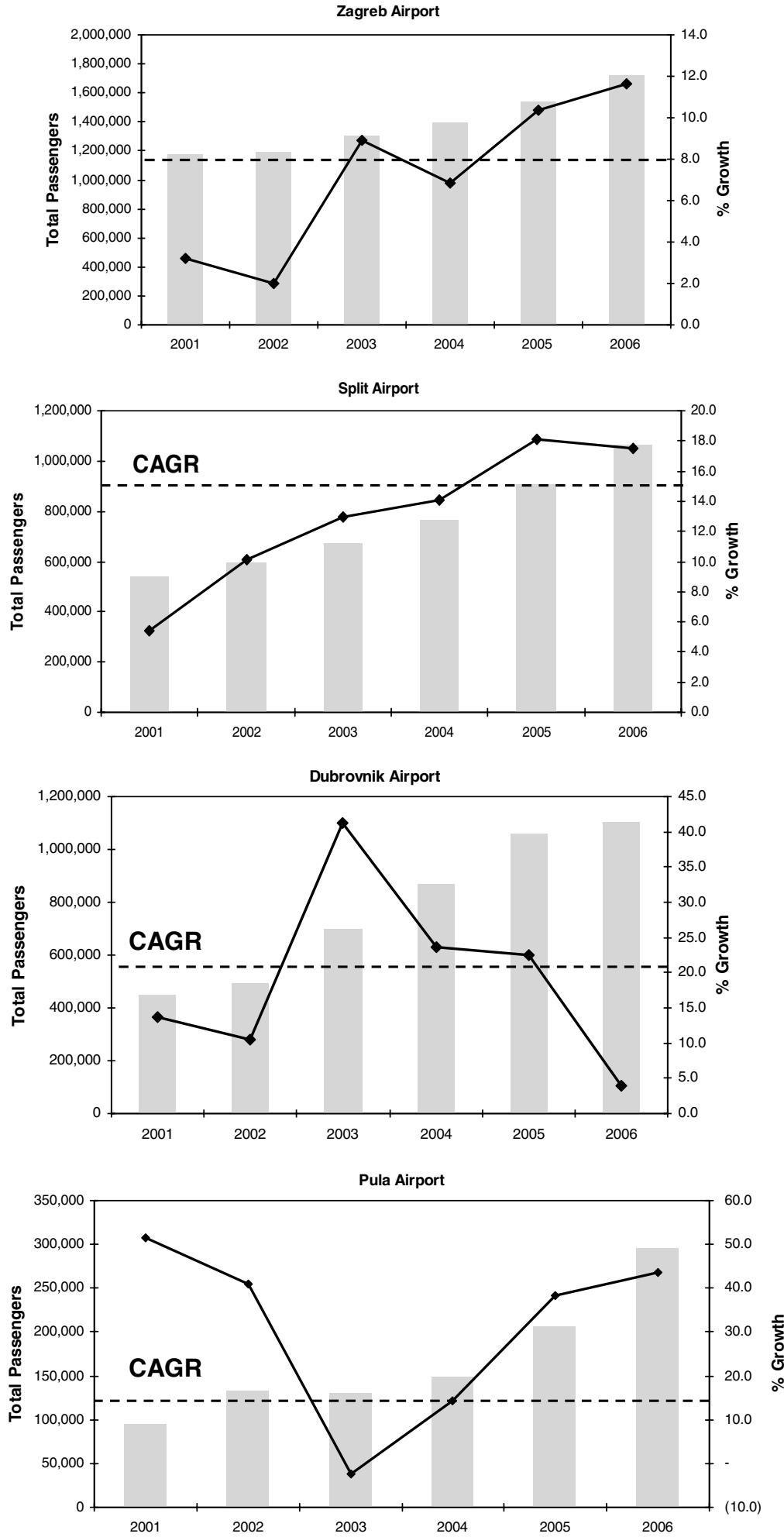

Figure 4: Passenger movements — Main Croatian airports 200I-2006 Source: ACI Worldwide Airport Traffic Report (199|-2006). 


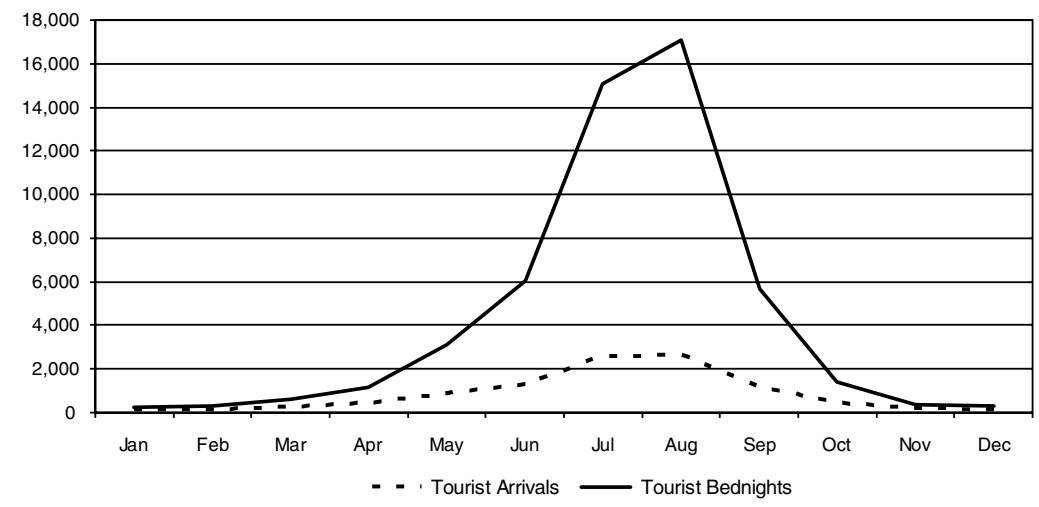

Figure 5: Monthly arrivals and bednights - Croatia 2005 (000s)

Source: Croatian Central Bureau of Statistics.

\section{TYPICAL COMPONENTS OF RESORT DEVELOPMENTS}

Resort developments are characterised by being a small destination in itself instead of just hotel accommodation. The following paragraphs describe typical resort components and highlight the specifics of the Croatian market.

\section{Hotel (including spa, conference facilities)}

The essential part of a resort is the hotel accommodation, which consists in most cases of an 80-150-room hotel. The hotel comprises adequate food and beverage facilities of mostly $2-3$ restaurants that offer the guests a variety of local and international cuisine.

In order to extend the season it is common to include a spa and conference facilities. The spa facilities usually comprise an indoor swimming pool, plunge pools, saunas, steam rooms, treatment rooms and a gym. The conference facilities, depending on the size of the resort, might comprise $1,500 \mathrm{~m}^{2}$.

\section{Hotel market in Croatia}

During Communist rule, low-quality hotels were built to cater for mass tourism. After the absence of tourism during the Balkan War, visitor numbers have been on the rise. But in contrast to the country's tourism under Communism, Croatia has taken the chance to rethink its tourism strategy and learn from the negative experiences of other Mediterranean countries. Therefore, the current Masterplan envisages repositioning Croatia as an upscale, luxury destination and to attract more individual travellers from Western European countries willing to pay premium prices.

However, at the moment most of Croatia's hotels are independent, unbranded hotels with many of them in need of refurbishment and/or upgrading. Recently, Croatia has appeared on the radar of the international operators and internationally branded hotels have opened in Zagreb (Sheraton, Four Points, Westin and Regent), Split (Le Meridien) and Dubrovnik (Hilton). Kempinski is currently constructing a resort 
in Savudrija, Istria and Rezidor is to introduce its Regent brand in Dubrovnik. Further branded hotels along the coast and in Zagreb are likely to follow soon.

\section{Golf}

As demand for golf is stronger during the shoulder months of March to June and October to November, it complements summer tourist demand and therefore helps to broaden the seasonality, and, hence, offers hotels the possibility to achieve higher occupancies.

An important factor for golf tourism in Croatia is the density of golf courses within a given area, so that golfers may play more than one course during their stay. The construction of golf courses may take up to three years on average, depending if it is a championship golf course.

Revenue from a golf course is mainly generated by green fees and membership fees as well as income from the pro shop, food and beverage in the clubhouse, golf lessons and golf services such as rentals of clubs, trolleys, buggies, caddies and driving-range balls. The main expense for a golf course is water costs that make up to about 50 per cent of all operating expenses.

Currently, the area of Croatia with the most golf course developments in the pipeline is Istria. Out of 23 locations planned for the construction of golf courses by the government in 1999 as many as 14 were situated in the Istrian region. This indicates that Istria will be taking the leading role for golf developments in Croatia.

There are plans for new golf developments in Istria; a total of 20 potential sites from the north to the southern tip of Istria are shown in Figure 6. Most of these sites still need final approval by the municipalities, including environmental effect studies.

According to the zoning plan of the Istrian region, the golf courses with 18 holes will range from 70 to 120 ha, depending on the natural features of the location, and courses with 27 holes will range from 100 to 160 ha, also depending on the natural features of the location.

From our discussions with the tourism board we understand that the first golf courses to open will be Savudrija (which is under construction and planned to open in autumn 2008), Motovun (mid-2008), Markocija (2009), Novigrad (2009) and Medulin, near Pula (autumn 2009).

At the moment, there are only two existing golf courses in Croatia: one in Zagreb and one on the island of Brijuni, near Pula. However, due to the favourable climate conditions, golf courses in Croatia can be operational year round and therefore they have the potential to attract significant demand from golf nations such as the UK, Germany, Austria, Italy and France. Table 1 illustrates the number of golf courses and players in European countries.

\section{Marina}

Marinas form part of resort developments that are located on islands or on the coast. The accessibility of the resort is then enhanced for arrivals by sea.

Marinas differ from most commercial properties in several ways. The value of a marina's land and site improvements, which include the bulkheads and piers, often outweighs the value of the building 


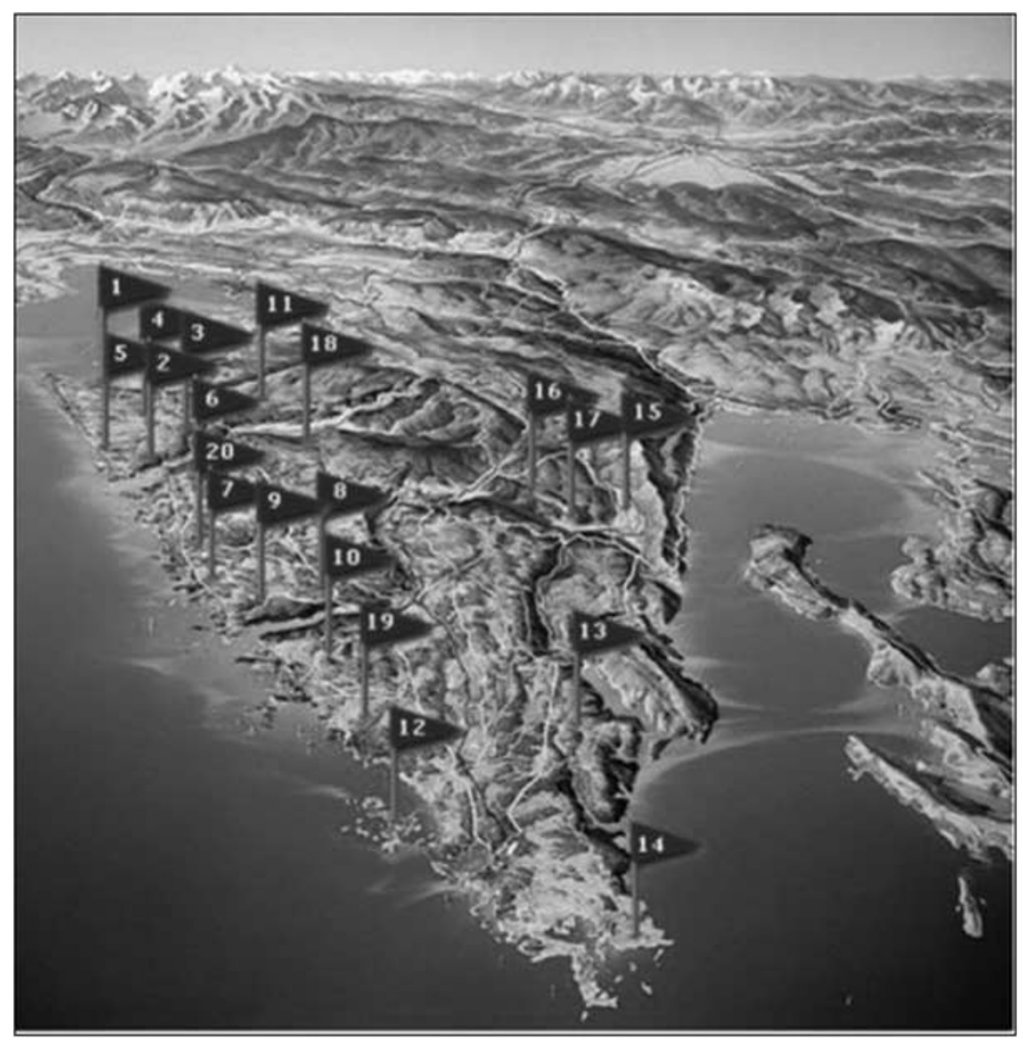

Figure 6: Potential golf developments — Istria

Source: Istria Department for Tourism

Key (I) 'Crveni Vrh' near Savudrija — approximately 75 ha; (2) 'Prašæarija' near Novigrad; (3) 'Markocija' near Umag — II 7 ha; (4) 'Mateliæi' near Umag — 120 ha; (5) 'Fratarska šuma' near Karigador — ha; (6) 'Tar-Mirna Stancija Špin' near Tar — approximately 110 ha; (7) 'Zelena laguna' near Poreè — approximately 90 ha; (8) ‘Kloštar' near Sv. Lovreè — approximately 100 ha; (9) 'Stancija Grande' near Vrsar — approximately 80-100 ha; (10) 'San Marko' near Rovinj — approximately 80-100 ha; (II) 'Vrnjak' near Grožnjan — approximately 80 ha; (I2) ‘Brijuni' on the Veliki Brijun Island — historic course of approximately 85 ha; ( I3) 'Loborika' near Loborika — approximately 80-100 ha; (14) 'Marlera' near Ližnjan — approximately 140 ha; (15) 'Dubrova' near Labin — approximately 80 ha; (16) 'Jakomiæi' near Piæan — approximately 80-100 ha; (17) 'Koz'ljak' near Kršan — approximately 80-100 ha; (18) 'Brkaè' near Motovun — approximately 120-150 ha; (19) 'Barbariga-Porto Mariccio' near Peroj — approximately II 0 ha; (20) 'Larun' near Ėervar — Poreè — approximately 80-100 ha.

improvements in all but the largest commercial projects. Additionally, more specialist knowledge is needed to operate a marina than for many types of general commercial properties which results in higher management allocations and more expensive insurance. Incomes for marinas are more diverse, and utility expenses are more varied.

In keeping with hotels and other commercial properties, marinas have income and expense sources. Sources of income at a marina include summer slip rental, winter wet and dry storage, overnight and temporary dockage, on-site storage, dry rack storage, boat washing, boat repairs, launch fees, boat services and petrol, oil and boat sales. Additional income may come from other businesses such as restaurants, bait and tackle shops, and buildings such as hotels, apartments or townhouses. Common expenses at a marina include real estate taxes, licences, insurance, utilities, advertising, management, legal and professional fees, employee wages, repairs and maintenance, reserves for replacement and other expenses. 
Table I: Golf course statistics for Europe 2006

\begin{tabular}{|c|c|c|c|c|c|}
\hline 2006 & Courses & Players & Male & Female & Juniors \\
\hline Austria & 152 & 95,833 & 52,165 & 33,447 & 10,221 \\
\hline Belgium & 78 & 48,351 & 26,465 & $|6,22|$ & 5,665 \\
\hline Bulgaria & 3 & 125 & 112 & 8 & 5 \\
\hline Croatia & 2 & 550 & 475 & 75 & - \\
\hline Cyprus & 9 & 1,400 & 1,000 & 300 & 100 \\
\hline Czech Rep. & 69 & 29,133 & $|7,09|$ & 7,285 & 4,757 \\
\hline Denmark & 160 & 140,507 & 87,374 & 41,110 & 12,023 \\
\hline England & 1,960 & 872,665 & 675,190 & 125,234 & 72,241 \\
\hline Estonia & 6 & 1,387 & 854 & 321 & 212 \\
\hline Finland & 117 & 116,473 & 68,932 & 32,071 & 15,470 \\
\hline France & 559 & 378,275 & 239,961 & 100,602 & 37,712 \\
\hline Germany & 677 & 527,427 & 285,193 & 186,044 & 56,190 \\
\hline Greece & 6 & 1,339 & 865 & 176 & 298 \\
\hline Hungary & 8 & 2,140 & 1,700 & 200 & 240 \\
\hline Iceland & 61 & 15,865 & 10,601 & 3,460 & 1,804 \\
\hline Ireland & 409 & 287,000 & 190,000 & 60,000 & 37,000 \\
\hline Israel & 2 & 1,300 & 900 & 300 & 100 \\
\hline Italy & 252 & 84,153 & 54,362 & 21,418 & 8,373 \\
\hline Latvia & 3 & 700 & 400 & 100 & 200 \\
\hline Luxembourg & 6 & 3,912 & 2,226 & $\mathrm{I}, 187$ & 499 \\
\hline Netherlands & 150 & 282,000 & 176,000 & 93,000 & 13,000 \\
\hline Norway & 154 & 119,165 & 74,977 & 29,059 & 15,129 \\
\hline Poland & 24 & 1,726 & 1,358 & 230 & 138 \\
\hline Portugal & 77 & 13,835 & 9,813 & 2,803 & 1,219 \\
\hline Romania & 4 & 590 & 410 & 80 & 100 \\
\hline Russia & 7 & 5,150 & 2,600 & 1,550 & 1,000 \\
\hline Scotland & 579 & 257,132 & 195273 & 34,360 & 27,499 \\
\hline Serbia & 1 & 300 & 200 & 50 & 50 \\
\hline Slovakia & 6 & 3,016 & 1,864 & 693 & 459 \\
\hline Spain & 303 & 310,822 & 204,930 & 93,684 & 12,208 \\
\hline Sweden & 442 & 539,637 & 313,537 & 146,573 & 79,527 \\
\hline Switzerland & 88 & 50,578 & 27,746 & 17,186 & 5,646 \\
\hline Turkey & 13 & 5,050 & 3,615 & 882 & 553 \\
\hline Wales & 158 & 64,012 & 48,533 & 7,400 & 8,079 \\
\hline
\end{tabular}

Source: European Golf Association, 2007

Shaded areas: Croatia and neighbouring countries or comparable countries-potential golfers coming from these countries to croatia

Croatia has a coastline of approximately $6,000 \mathrm{~km}$ and more than 1,100 islands and, therefore, there are fantastic opportunities for sailing. Although Croatia contains 15 per cent of the Mediterranean coast line, the country has only 2.6 berths per kilometre (compared to 64 in France, 20 in Spain, six in Italy and one in Greece). In total, Croatia has about 50 marinas with a capacity of approximately 15,000 sea berths and 5,500 dry berths. Of these marinas, 21 are owned by the government-run Adriatic Croatia International Club and they are in need of refurbishment as many of them were built 25 years ago. Furthermore, they are not equipped to accommodate superyachts.

During this year's Croatian Boat Show the Minister for Sea, Tourism, Transport and Development announced that 10,000 new wet moorings and 5,000 land moorings will be built up until 2017, with some of them as part of a resort or next to one.

Croatia's nautical tourism is said to be growing at about 10 per cent each year and to generate more than $€ 700 \mathrm{~m}$ in annual revenue. There are currently about 105,000 registered boats in Croatia, and another 160,000 boats are estimated to visit its waters each year. Increasingly, 


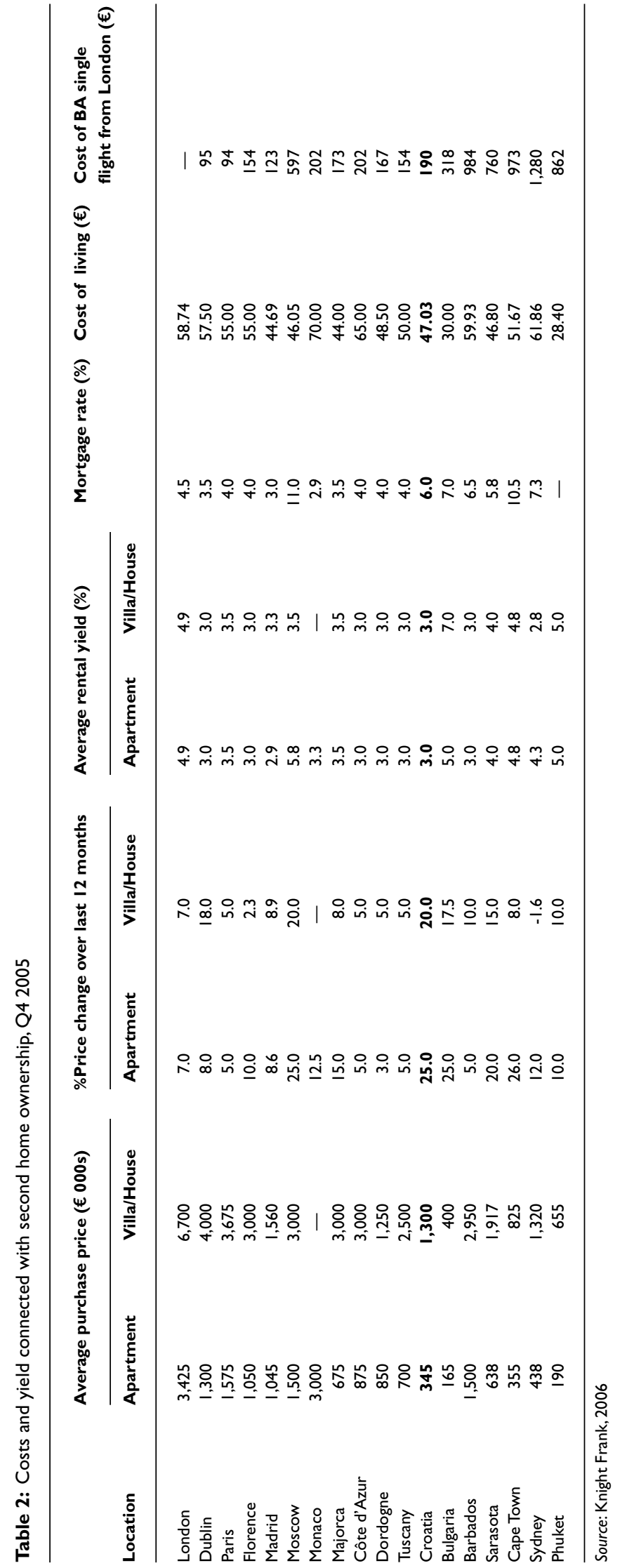


good infrastructure triggers rising demand from Austria, Germany and Switzerland as well as from the very large British, Irish and French sailing communities.

The demand for marina berths in the Mediterranean is currently exceeding supply. For medium to large yachts $(30 \mathrm{~m}+)$, particularly, waiting times can be up to 20 years for annual berths (for example, in Nice or Cannes). Croatia has therefore seen a chance to get into the market for superyachts and plans to open new marinas catering for the demand of larger yachts $(25 \mathrm{~m}+)$ in Pula, Zadar, Split and Dubrovnik as part of the Marine Tourism Strategy.

\section{Residential villas and apartments}

Croatia, especially its coastline, is considered by many to be one of Eastern Europe's major emerging property markets, becoming a hotspot as a second-home destination or an area for property investment. However, as any other emerging market, Croatia is not risk free and issues such as bureaucracy, an unregulated property market, legal hindrances and restrictions on foreign real estate ownership make property acquisition difficult. What is certain is that prices are rising rapidly, but so far they remain far less than in the popular developed coastal areas of other Mediterranean countries.

According to a report issued by Knight Frank, prices for residential real estate are up to 65 per cent lower than those witnessed in the more mature European countries, while rental yields in Croatia are estimated to be around 3 per cent, broadly comparable to a range of $3-5$ per cent in most other countries.

Table 2 depicts some of the prices and costs related to the purchase of a second home in Croatia and alternative destinations. Croatia is clearly attractive from an investment viewpoint, with a 25 per cent growth in sales prices for apartments in 2005 and 20 per cent for villas, especially along the Adriatic coast. Hotspot locations vary according to buyer preferences but luxury properties are still in short supply. Croatia has attracted a considerable proportion of investors and this will continue as long as the promise of high returns does.

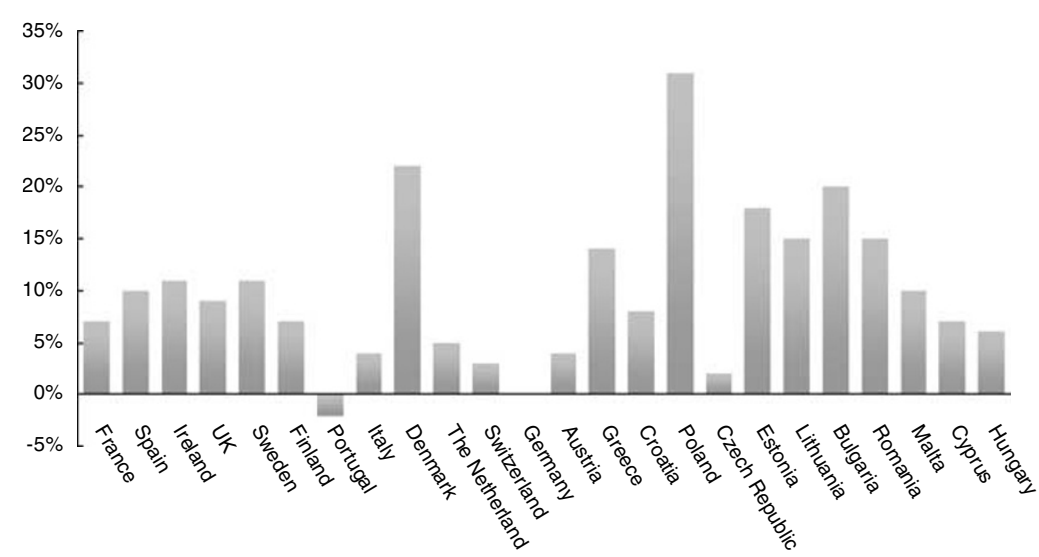

Figure 7: House price inflation 2005/06

Source: RICS European Housing Review 2007. 
Figure 7 shows the nominal increase in house prices, or capital gain, in Croatia and other European countries for 2005/06. The Croatian capital experienced inflation in the region of 7 per cent according to King Sturge Croatia Property Market 2007, whereas on the Adriatic coast prices of luxury accommodation have displayed significant increases, clearly above average.

There is currently a lack of luxury residences in the Croatian market. Based on our discussions with local agents, we understand that two and three-bedroom apartments are in great demand. However, quality fourbedroom villas are also needed.

Residential developments can achieve additional premiums if they are located next to a golf course, waterside or marina or included in a resort enabling the owners to use all the facilities and amenities. Additionally, residences as part of a resort development and/or with an international operator are able to achieve a premium on the sales prices. Current examples are the developments in Punta Scala (managed by Falkensteiner) or Savudrija (Kempinski).

The key buyers of property in Croatia are predominantly from Western Europe (Germany, England, Italy, Austria and France), Slovenia and, to a lesser extent, Croatia. We note that a foreigner wishing to buying property in Croatia still faces a difficult procedure, one that can take up to two years. However, we understand that there are legal ways to avoid this procedure, such as registering as a local business.

\section{Rental pool}

The concept of the rental pool is attractive to both owners and managing companies and it is gaining in popularity in mixed-use resorts around the world. The management of the apartment/villa units in the rental pool is mostly done by the adjacent hotel. The owner of a rental pool residence occupies the residence for approximately 6-8 weeks a year on average, with the option of renting it out for the remaining time. Owners would typically expect a return of 3-7 per cent in the stabilised year, depending on the market. Commission payable to the owner is between 40 and 60 per cent of total revenues and the operator receives the remaining 60-40 per cent of total revenues. Maintenance expenses are usually borne by the owner. For the operator expenses total approximately 30-40 per cent .

In Croatia, there is a special legislation that does not allow any sales of residential units on a freehold basis on a T2 zoning (specific for tourist use such as hotels or a resort). It is widely expected that this issue can be bypassed through, for example, the creation of a club which would own this asset and buyers would acquire shares in the club. There may be other means but this is currently being tested. It is hoped that in the near future the legislation will be changed to allow the sale of residential freehold in $\mathrm{T} 2$ zoning, but it remains uncertain at this stage.

\section{CASE STUDY}

Although the future for luxury developments in Croatia looks promising, we note that the country has just started to position itself as an upscale 
Table 3: Example profit and loss statement of a hotel development in Croatia

\begin{tabular}{|c|c|c|c|c|c|c|c|c|}
\hline & 2009 & & 2010 & & 2011 & & 2012 & \\
\hline Number of rooms: & 150 & & 150 & & 150 & & 150 & \\
\hline Occupied rooms: & 30,113 & & 32,850 & & 34,493 & & 35,588 & \\
\hline Occupancy: & $55 \%$ & & $60 \%$ & & $63 \%$ & & $65 \%$ & \\
\hline Average rate: & 160.00 & & 168.00 & & 175.00 & & 180.00 & \\
\hline RevPAR: & 88.00 & $\%$ of gross & 100.80 & $\%$ of gross & 110.25 & $\%$ of gross & 117.00 & $\%$ of gross \\
\hline \multicolumn{9}{|l|}{ Revenue } \\
\hline Rooms & 4,818 & 60.9 & 5,519 & 62.2 & 6,036 & 63.1 & 6,406 & 63.5 \\
\hline Food and beverage & 2,873 & 36.3 & 3,122 & 35.2 & 3,301 & 34.5 & 3,447 & 34.1 \\
\hline Other income & 216 & 2.7 & 226 & 2.5 & 234 & 2.4 & 240 & 2.4 \\
\hline Total & 7,907 & 100.0 & 8,866 & 100.0 & 9,571 & 100.0 & 10,093 & 100.0 \\
\hline \multicolumn{9}{|l|}{ Departmental expenses* } \\
\hline Rooms & 886 & 18.4 & 933 & 16.9 & 970 & 16.1 & 1,002 & 15.6 \\
\hline Food and beverage & 2,001 & 69.7 & 2,097 & 67.2 & 2,174 & 65.8 & 2,240 & 65.0 \\
\hline Other expenses & 156 & 72.4 & 161 & 71.2 & 165 & 70.5 & 168 & 70.0 \\
\hline Total & 3,044 & 38.5 & 3,191 & 36.0 & 3,308 & 34.6 & 3,411 & 33.8 \\
\hline Departmental income & 4,863 & 61.5 & 5,675 & 64.0 & 6,262 & 65.4 & 6,683 & 66.2 \\
\hline \multicolumn{9}{|c|}{ Undistributed operating expenses } \\
\hline $\begin{array}{l}\text { Administrative and } \\
\text { general }\end{array}$ & 915 & 11.6 & 953 & 10.8 & 986 & 10.3 & 1,014 & 10.0 \\
\hline Marketing & 381 & 4.8 & 397 & 4.5 & 411 & 4.3 & 422 & 4.2 \\
\hline $\begin{array}{l}\text { Prop. operations and } \\
\text { maint. }\end{array}$ & 419 & 5.3 & 437 & 4.9 & 452 & 4.7 & 465 & 4.6 \\
\hline Utilities & 305 & 3.9 & 318 & 3.6 & 329 & 3.4 & 338 & 3.3 \\
\hline Total & 2,020 & 25.6 & 2,105 & 23.8 & 2,176 & 22.7 & 2,238 & 22.1 \\
\hline Gross operating profit (GOP) & 2,843 & 35.9 & 3,570 & 40.2 & 4,086 & 42.7 & 4,444 & 44.1 \\
\hline Management fee & 237 & 3.0 & 266 & 3.0 & 287 & 3.0 & 303 & 3.0 \\
\hline GOP after management fees & 2,606 & 32.9 & 3,304 & 37.2 & 3,799 & 39.7 & 4,141 & 41.1 \\
\hline \multicolumn{9}{|l|}{ Fixed expenses } \\
\hline Property taxes & 95 & 1.2 & 97 & 1.1 & 99 & 1.0 & 101 & 1.0 \\
\hline Insurance & 95 & 1.2 & 97 & 1.1 & 99 & 1.0 & 101 & 1.0 \\
\hline $\begin{array}{l}\text { Incentive management } \\
\text { fee }\end{array}$ & 208 & 2.6 & 264 & 3.0 & 304 & 3.2 & 331 & 3.3 \\
\hline Reserve for replacement & 158 & 2.0 & 266 & 3.0 & 383 & 4.0 & 404 & 4.0 \\
\hline Total & 557 & 7.0 & 724 & 8.2 & 885 & 9.2 & 937 & 9.3 \\
\hline Net operating income & 2,049 & 25.9 & 2,580 & 29.0 & 2,914 & 30.5 & 3,205 & 31.8 \\
\hline
\end{tabular}

*Departmental expenses are expressed as a percentage of departmental revenues.

destination but it is not yet established. Therefore, average rates for luxury hotels are at the moment remarkably lower than in established Mediterranean countries.

We have prepared an indicative profit and loss statement of an example five-star luxury hotel. We note that this profit and loss statement was derived from our experience in the market as well as from existing hotels, from which we used average profit and loss data to reflect a standard fivestar hotel operation. 
Table 3 shows the first four years of operation, assuming that the example hotel has 150 rooms and is open year round. All projections are expressed in Euros. After the fourth year of operation we consider that the hotel will be stabilised and therefore all income and expense would increase with inflation at 2 per cent, according to the Economist Intelligence Unit's forecast for Euro inflation.

By using the income capitalisation approach we arrive at a value of the example hotel. The income capitalisation approach is based on the principle that the value of a property is indicated by the net return to the property, or what is also known as the present worth of future benefits. The future benefits of income-producing properties, such as hotels, are net operating income, derived by a forecast of income and expense, and any expected reversionary proceeds from a sale. These future benefits can be converted into an indication of value through a capitalisation process and discounted cash flow analysis. Applying a terminal capitalisation rate of 9 per cent, a loan-to-value of 70 per cent and equity yield of 18 per cent derives a value of approximately $€ 200,000$ per room.

Therefore, a developer should try not to exceed the $€ 200,000$ limit if a return on investment is wanted. However, we note that there are several ways to increase the value of the hotel and/or resort, which would then justify a higher development cost. First of all, residential sales and rental pool programmes offer the possibility to get sales proceeds as well as increasing the income for the hotel operation (assuming that the hotel manages the rental pool). Furthermore, extensive spa and/or conference facilities might add to the hotel's profit and induce demand in the shoulder months, depending on the local market conditions that need to be analysed beforehand. Another possibility is an attached golf course that increases the sales value of the residential development (if there is any) and broadens the season for the hotel, which means a higher annual occupancy. The last possibility is an adjacent or included marina that is likely to increase the value of the residences (if there are any) and generate additional demand for accommodation and food and beverage in the shoulder months.

\section{CONCLUSION}

Croatia shows significant tourism potential due to its beautiful landscape, its warm climate, many culinary traditions (such as wine, olives and truffles) and almost $6,000 \mathrm{~km}$ of coastline including more than 1,100 islands that offer a variety of sports and recreational activities.

Croatia has just started to be re-discovered by Western and Northern European feeder markets as an unspoilt Mediterranean destination. After the absence of tourism during the Balkan War in the 1990s, Croatia has taken the chance to rebuild tourism on a more sustainable basis and now wants to position itself as luxury destination. The first branded hotels have entered the market but there is still enormous growth potential.

However, there are also some drawbacks. Seasonality restricts annual hotel occupancy to about 60-70 per cent and average rate in the five-star segment, at about $€ 150$, is still remarkably lower than that of other Mediterranean countries. 
Therefore, as explained in the case study, the development costs for a hotel should not be higher than $€ 200,000$ per room to make the hotel operation profitable. For a resort development overall profitability drivers are residential sales, rental pool programmes and additional facilities such as spas, conference centres, golf courses or marinas.

With more branded luxury hotels and resorts entering the market and global distribution systems marketing Croatia worldwide, in the mid to long term, hotel rates are likely to increase to levels experienced in other Mediterranean countries. 